\title{
Shan Buddhist art on the market: what, where and why?
}

\author{
By Catherine Raymond* ${ }^{1}$ \\ [incomplete draft]
}

\begin{abstract}
When looking through a collection of Buddha images of Burmese-origin from any given period, the Shan pieces are somehow easily recognizable. Yet systematic typological studies of distinctively Shan Buddhist art are still largely absent from the iconographic research: paralleling our slender knowledge of the particularity of Shan Theravada Buddhist practice.
\end{abstract}

Due in part to arguably chauvinistic aspects of Myanmar's admirable commitment to cultural conservation, Shan art and Shan religion are clearly de-prioritized now in defining and protecting the "national patrimony". Thus, Shan artifacts appear to figure disproportionately large within the contemptible international trade in prima facie stolen religious artwork: as evidenced from the antiquary markets in Bangkok, Chiang Mai, Hong Kong and Singapore; and from the advertisements in the Asian art collectors' magazines. Indeed, such a de-contextualizing of Shan art is precisely a component of a "Heritage in Danger".

\footnotetext{
${ }^{1} *$ Catherine Raymond is Director of the Center for Burma Studies at Northern Illinois University (NIU), and Associate Professor of Southeast Asian Art History. She received her a doctorate from La Sorbonne and holds degrees also from INaLCO, Paris. In addition to her curatorship of the NIU Burma Art Collection, the focus of much of her research and teaching, she has contributed both to the study and to the material conservation of Lao Buddhist sculpture and wall paintings, especially with the collections of the Vat Sisaket and Ho Phrakeo museums in Vientiane. Her central interest is in the commonality and specificity of Buddhist iconography across Lane Xang, Lanna and Burma.
} 
The two parts of my presentation for the SOAS Shan conference would be:

- a very preliminary iconographic comparison of Shan and non-Shan Buddha images in the Burma Art Collection of Northern Illinois University, in De Kalb Illinois, USA (which, of course, is predominantly Burman); and also the collections of the "Lane Xang" Buddhas in the Ho Phrakeo and Vat Sisaket museums in Vientiane, which are predominantly Lao and Lanna in origin, and presumably hold greater commonality with the Shan traditions.

- an eyeball survey — backed where possible by photography — of recognizably Shan, or assertedly Shan artifacts presently or recently on sale to an international clientele, e.g., at the River City emporium, or advertised in such reputable journals as Orientations and Arts of Asia.

\section{Shan Buddha Images at NIU and their links with the neighboring countries}

In considering their provenance, knowing they had been bought in Thailand after the coup d'État by Ne Win in 1962, I questioned if the comparison with dated Buddha images in quite the same style from the two former kingdoms Lan Na and Lan Xang, which were both under Burmese "patronage" between 1550 and 1772, could prove more informative as to how to better define Shan art.

For Northern Thailand the previous studies undertaken by Griswold ${ }^{2}$ and more recently by Woodward ${ }^{3}$, Fickle $^{4}$ and Stratton ${ }^{5}$, give us a wide range of new information regarding

\footnotetext{
${ }^{2}$ See Griswold, A. B. 1957 Dated Buddha Images of Northern Siam. In Artibus Asiae. Supplementum, Vol. 16, Dated Buddha Images of Northern Siam; and Griswold, A. B. 1959, Two Dated Images from the Shan States. In Artibus Asiae, Vol. 22, No. 1/2. pp. 59-63.

${ }^{3}$ Woodward, Hiram W., 1997. The Sacred Sculpture of Thailand.River Books. pp. 207-226. As he underlines. "More is known about political and monastic affairs than about stylistic development..."

${ }^{4}$ Fickle, Dorothy H. 1974. "Crowned Buddha Images in Southeast Asia". Art and Archaeology in Thailand.Bangkok: Fine Arts Department, pp. 85-119.
} 
Buddhist sculpture of which the provenance was the present Northern Thailand. But we do not yet have quite the same breadth of knowledge from the former kingdom of Lan Xang in Laos, apart from the study by Gagneux ${ }^{6}$ of Lao epigraphy, published in part by Giteau $^{7}$, and Giteau's own study of the collection of the Ho Phra Keo Museum in Vientiane. The information is still very limited and but various projects presently underway should in the near future better instruct us how to relate these collections to the larger area.

One of the common factors amongst Burmese Shan seated Buddha images and also Lan $\mathrm{Na}$ and Lan Xang seated Buddha images is the maravijaya posture. Indeed, this is the most prevalent posture in mainland Southeast Asian Buddhist iconography, where the seated Buddha extends his right hand towards the Earth Goddess to call her to witness. But if we more carefully look the seated Buddhas from Lan Na and Lan Xang the majority of the statues - the earlier examples in bronze and later in wood or in lacquerthe asana displayed is ordinarily virasana, with the exception of examples of the so-called "Singhalese" or Phra Singh type, which are in padmasana. more often associated with the dhyanamudra. This "full lotus" position - where the two soles of the feet are both visible - is also the one found on the majority of seated Buddha images from the Shan States.

This tends to be confirmed by the NIU Burma Art Collection's Buddha image (BC 86.01.07.00, dated by inscription equivalent to 1885) which is the only one with an inscription in yuan and is indeed in virasana. The others, inscribed in khun, are in

\footnotetext{
5 Stratton, Carol. 2004, Buddhist Sculpture of Northern Thailand, Silkworm Books.Burmese /Lan Na type.pp. $290-294$.

${ }^{6}$ Gagneux Pierre Marie,1975, Contribution à la connaissance de la Civilisation Laotienne d'après l'épigraphie du royaume de Vientiane (XVème - XIXème siècles),EHESS, Paris.

7 see Giteau Madeleine. 2001. Art and Archeologie du Laos, Picard, Paris.pp.145-167 where she presents an analysis of her previous studies of the Royal collection in Luang Prabang, see her article in Arts Asiatiques, t. XVI. 1973 and her UNESCO report for the Ho Phra Keo collection, 1969.
} 
padmasana. As noticed by Finot ${ }^{8}$ and more recently by Pelletier ${ }^{9}$, yuan script is indicative of the Chieng Mai and Chieng Rai region, although it is affiliated with the tham (in Laos) the Lu (in Sipsong Panna), the Khun (in Shan States).

Finot also notes that the first Shan inscriptions found in Laos date from 1550 and $1560^{10}$. This date coincides with the beginning of the extension of the Burmese Empire, which for over two centuries would assert its authority over Lan Na, and episodically, over Lan Xang.

So we can assume the religious exchange between Lan Xang and Shan States via Lan Na were existing and we know from the account left by Van Wuysthoff, a Dutchman serving as a VOC agent who visited Vientiane in 1641, that the Lan Xang Kingdom was flourishing at that time ${ }^{11}$.

Amongst the limited number of dated Shan pieces (seven) in the NIU Collection, I found especially interesting two of the dry lacquer Buddhas, of which the hair is made of lacquer. Lacquer hair of a similar technique and style was commonly applied to the heads of Lao bronze Buddha images dating as early as the 15th century and was still very popular as late as the 18 th century. ${ }^{12}$

\footnotetext{
${ }^{8}$ Finot, Louis, 1917. Recherches sur la littérature laotienne, Bulletin de l'École Française d'ExtrêmeOrient, XVII/V, pp.26. This is still the most comprehensive study on the subject.

${ }^{9}$ Peltier, Anatole-Roger.1987.La Littérature Tai Khoeun. Tai Khoeun Literature. Editions Duang Kamol, École Française d'Extrême-Orient and Social Research Institute Chiang Mai University.

For the last 20 years A.R Peltier has been collecting documents in various Khun languages, see Fonds Anatole-Roger Peltier, at EFEO, Chiang Mai, Thailand.

For comparison you may also refer to his tables presenting the four writing: tham, khoeun, yuan and lu, Peltier 1990. Les littératures Lao du Lan Na, du Lan Xang, de Keng Tung et de Sipsong Panna. Peninsule, 21, vol. 2. pp. 29-45. An overview of his work is also presented in English in Goudineau, Yves. (eds.) 2003 Laos and ethnic Minority Cultures:Promoting Heritage. UNESCO, Paris.

${ }^{10}$ Finot 1917:26-27. Finot classified the Shan writting into three categories with minor differences in the lettering : the Tham used in Laos mainly for religious purposes, the lu used in North of Laos essentially in Sipsong Panna and the yuon used in Xieng Mai area touching Xieng Tong.

${ }^{11}$ Lejosne, C.1987. Le Journal de voyage de G. Van Wyusthoff et de ses assistants au Laos (1641-1642). Paris CCRL.

${ }^{12}$ Giteau, 2001: in bronze 153 fig.113 and 156 fig.118, in lacquer 161 fig. 128.
} 
Ideally, a more ambitious study could be pursued in comparing a much larger number of dated Buddha images, along the lines of the research by Professor Than Tun 13 from Pindaya cave in the western part of Shan States. We'd like also to see a future major survey of inscribed Buddha images found in the 22 monasteries of Kengtun, Shan State.

\section{Shan Art on the market}

Compared to the extensive investigations on Lan Na culture over the last decades, very little work has been done on Shan culture, for which we need to be particularly appreciative of those who have taken it on. ${ }^{14}$

Yet, while the iconographic knowledge of Shan Buddha images is sparse, Shan artifacts appear to figure disproportionately large within the contemptible international trade in prima facie stolen religious artwork: as evidenced from the antiquary markets in Bangkok, Chiang Mai, Hong Kong and Singapore; and from the advertisements in the Asian art collectors' magazines. Indeed, such a de-contextualizing of Shan art is precisely a component of a "Heritage in Danger".

See, for example, this extract from the website of a well-known dealer:

"Our offerings come from private collectors, from museum de-accessions, and from our travels in the remote areas of Burma, Cambodia, Laos, Viet Nam, and Nepal. But our chief source is Thailand, the Asian capital for antique art.

\footnotetext{
13 Than Tun, 1982. Pindaya (in Burmese), Mandalay and Than Tun, 2003. Nay Lhañ̃ rāja van, (Chronicle of Nai Lhann) Pyi Zone Publishing House, Yangon. pp. 67-156

${ }^{14}$ Fraser Lu, Sylvia. 1994. Burmese Crafts Past and Present. Oxford University Press, Kuala Lumpur. pp.. Galloway, Charlotte, 2002. An introduction to the Buddha images of Burma. In Tasaa review, vol.11, No1, March. pp. 8-10. Conway, Susan. 2006, The Shan Culture, Art and Crafts, River Books
} 
"We never deal in stolen antiques or looted antiquities, and salaried, adult craftsmen make our new pieces. Each member of our consortium has its own network, which vastly extends Azibaza's reach. If you want something not on display, ask us for it: our networks will in all likelihood be able to uncover it for you." 15

This brazen website also claims that its proprietor is "officially" present (whatever that may mean) in Asia, in Europe and in America. Dealers like these ordinarily receive artifacts through a network of local agents. Such middlemen serve both to insulate dealers from the potential physical danger entailed in unsavory acquisitions, and to create plausible deniability regarding illegal trafficking in antiquities.

The artifacts here are marketed not to sophisticated collectors with some understanding of Buddhist iconography, but rather — with a shallow pitch towards purchasing décor pieces lending "peace and serenity" to lifestyle consumers looking to upgrade their interior design. It used to be that somebody wanting a Buddha head had to go, e.g., to River City in Bangkok, but now a few clicks on the computer will have it dispatched to him straightaway. The likely increasing demand bodes ill for the in-situ conservation of cultural properties.

And what could be more pleasing to even the most naive new collector wanting to participate in an exotic experience than a Burmese Buddha, or more specifically, a Shan gilded Buddha image with a smiling face adorned with semi-precious stones or glass inlay work?

To combat such traffic UNESCO passed the 1970 UNESCO Convention for Preventing the Illicit Traffic in Cultural Property. ${ }^{16}$

\footnotetext{
${ }^{15}$ http://www.azibaza.com/more.php retrieve in November, 2007.

16 "Signatories to the 1970 UNESCO Convention." Bureau of Education and Cultural Affairs. 10 Nov. 2005. United States of America. 23 Nov. 2006 http://exchanges.state.gov/culprop/unesco02.html
} 
In Myanmar, in 1998, due to the increase of tourism, the Archaeology Department prepared the Protection of Cultural Heritage Regions Law which includes "stupa...monastery, carving, image and painting thereon. ${ }^{17}$ "

The greatest defect of Myanmar's Cultural Heritage Law, as well as analogous laws in the Lao PDR and Cambodia, is that the demand for such objects is neither addressed nor alleviated. Most exported artifacts pass through Thailand, yet Thailand is not a signatory to the UNESCO 1970 convention. While this is obviously beneficial to the countless Thai traffickers in illegal antiquities, one wonders why insufficient international pressure has been brought to bear to change this in nearly forty years.

http://www.grad.niu.edu/burma/

http://www.cseas.niu.edu/centerfaculty/craymond/craymond.htm

\footnotetext{
${ }^{17}$ Myanmar. State Peace and Development Council. The Protection and Preservation of Cultural Heritage Regions Law. 10 Sept. 1998.
} 